\title{
ERRATA
}

\section{THICK FILMS OF YBaCuO FROM PRECALCINED POWDERS}

L. RAO MADHAVRAO and RAJ RAJAGOPALAN

[INT. J. MOD. PHYS. B, Vol. 3, No. 5 (1989) 751-761]

On page 751 , the citations for references 1 through 14 should be inserted after the first line in the 'Introduction' section. 